\title{
Sonographic Assessment of the Fetal Heart Circumference as a Predictor of the Gestational Age
}

1 Carnot N Ntafam

2 Nwobi Ivor

1 David Otohinoyi

1 Okikiade Adedeji

3 Joseph Dimas

1 All Saint University School of Medicine, St Vincent Campus

2 Department of Radiography, University of Maiduguri

3 Department of Radiology, Federal Medical Centre, Katsina

\section{Abstract}

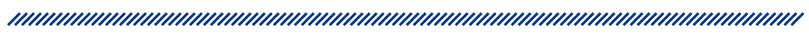

Introduction: Ultrasound is a non-invasive imaging modality, safe for both the mother and the fetus, which uses a high frequency sound to generate images of body tissues and organs. It has been widely used for fetal evaluation and dating.

Purpose: To determine normative values of fetal heart circumference $(\mathrm{FHC})$ as a predictor of the gestational age (GA) in black population and compare it to those of the Caucasian population.

Material and Methods: A prospective cross-sectional study was carried at the University of Maiduguri Teaching Hospital (UMTH), Nigeria. 324 women with a singleton pregnancy between $12-40$ weeks, who conceived naturally, were scanned using a 2D ultrasound machine with a 3.5 MHz curvilinear probe. Two fetal heart diameters at right angle to each other were taken at the level of the four-heart chamber view, during diastole.
Results: There is a strong positive linear correlation between the FHC and the GA ( $r 2=0.964, p<0.001)$. The equation of GA prediction is $\mathrm{Y}=0.246 \mathrm{X}+5.06$ (where $\mathrm{y}=\mathrm{GA}, \mathrm{X}=\mathrm{FHC}$ ). $\mathrm{FHC}$ weekly growth rate is $3.81 \mathrm{~mm}$. $\mathrm{FHC}$ is more accurate between $12-20$ weeks GA and its accuracy decreases as the pregnancy progresses. There is a strong correlation between $\mathrm{FHC}$ and biparietal diameter (BPD) ( $r 2=0.959), \mathrm{HC}(\mathrm{r} 2=0.946)$ and $\mathrm{FL}(\mathrm{r} 2=0.962)$.

Conclusion: The study has derived a nomogram of FHC as a predictor of the GA in Nigerian population and has shown that the $\mathrm{FHC}$ is a good predictor of GA especially in the early second trimester. Also, there was a statistically significant difference between the FHC in our study population (blacks) and those of the Caucasian population.

Keywords: Fetal Heart circumference (FHC), Gestational age (GA), Ultrasound scan, nomogram

Article received: 08.02.2021.

Article accepted: 15.04.2021.

https://doi.org/10.24141/1/7/2/3

Corresponding author:

Carnot N Ntafam

A: All Saints University School of Medicine, Saint Vincent \&

The Grenadines

E-mail: carnotntafam@gmail.com 


\section{Introduction}

Ultrasound has proved to be a useful and accurate method of determining the GA of the fetus $[1,2]$. It has advanced the assessment of fetus in utero, including accurate estimation of the GA when performed in the first half of the pregnancy [3]. Accurate assessment of GA is the most useful contribution sonogram has made to obstetric practice [4]. It is important to find new parameters to measure fetal growth that correlate with fetal age so that fetuses that are not growing well can be identified and treated [5]. Studies have supported that the use of multiple parameters improves the accuracy of fetal age and weight estimation [6]. The combination of more than one parameter should be used to increase the reliability, sensitivity and accuracy of fetal biometry [7]. Several sonographic fetal measurements are used nowadays to determine the GA: Crown rump length (CRL) $[8,9]$, the BPD $[10,11]$, the femur length $(F L)[5$, 12], the fetal kidney length (FKL) [13], head circumference (HC) [14], fetal foot length (FFL) [7] and FHC [15].

In placental vertebrates, the heart is the earliest major organ to function [16]. However, the FHC is seldom used to predict the GA in our locality. There are very few literature sources/articles that demonstrate the relationship and correlation between GA and FHC using sonogram/echocardiogram which is mostly used for assessing various fetal cardiac anomalies (congenital heart disease). Sonogram is useful in fetal heart assessment and can be an early predictor of fetal heart anomaly [17]. Also, there is little previous information about the FHC growth pattern; and the normal values at our disposal are those of Caucasians which are likely to be different due to racial differences.

\section{Material and Methods}

A prospective cross-sectional study conducted at UMTH with participants selected mainly from the antenatal clinic; from April 2015 to March 2016. Approval was obtained for the research committee of the UMTH and ethical standard in accordance with the Helsinki dec- laration of 1975 as revised in 2000 was adopted [18]. The participants' consent was requested with regard to using their fetuses' parameters for research purpose. Measurements were taken only on those who accepted.

324 women underwent obstetric ultrasound scans using a two-dimensional ultrasound machine with good resolution (Aloka Prosound SSD-3500 PLUS) and with a $3.5 \mathrm{MHz}$ curvilinear probe. The age, tribe and parity of the women were also taken. The inclusion criteria were: singleton fetus, pregnancy from 12 weeks and above, no history of prolonged maternal illness, no fetal abnormality or deformity. Exclusion criteria were: multiple gestation, any fetal deformity, fetal growth restriction, maternal diabetes and/or hypertension, uterine and/or placental anomalies, maternal substance abuse, smoking and alcohol.

Scanning technique: Ultrasound scans were carried out by a sonographer with more than 17 years of experience. The patient lied either supine or in semi-Fowler position with her legs extended on the examination bed. Using a $3.5 \mathrm{MHz}$ curvilinear transducer, the patient was scanned. A general survey (sweep) was initially performed to ensure that the fetus, the placenta and the uterus are all normal. The four-heart chamber view was used as landmark for measurement of the FHC. The FHC was measured during diastole, using the method described by Jeanty et al, [19] and Jordaan et al [16].

The FHC was derived using these two formulas: HTC= $\pi\left(D_{1}+D_{2}\right) / 2$ and $H T C=\pi \sqrt{ }\left\{\left(D_{1}^{2}+D_{2}^{2}\right) / 2\right\}$; assuming that the cross section of the heart at the four-heart chamber view is oval in shape. A two-tailed student T test showed that there was no significant difference between the values obtained from the two formulas used to derive the FHC $(p \leq 0.995>0.05)$.

The BPD was measured from the proximal edge to the proximal edge of the deep border [20]. The transducer was placed perpendicular to the central axis of the head, such that the hemispheres and calvaria appeared symmetrical, with the midline falx, the thalami symmetrically positioned on either side of the falx and visualization of the septum pellucidum at one of the frontooccipital distance. The cerebellar hemispheres should not be in the plane of the image. [21, 22]

The HC was obtained at the same plane with the BPD using the measurement of an ellipse around the outer calvaria.

The FL was measured using the fetal thigh closer to the transducer, from the major trochanter to the lateral femoral condyle along the longest axis of the central shaft exclusive of the epiphyses. [10] 
Due to some factors such as faulty memory, bleeding in early pregnancy and the use of contraceptives, the last menstrual period (LMP) as a gold standard has several potentials of inaccuracy [23]. For those reasons the LMP was not used. Rather our measurements were correlated to the average GA obtained from the BPD, HC and FL. This is because the combination of more than one parameter increases the reliability, sensitivity and accuracy of fetal biometry [7] and allows the fetuses that are not growing well to be identified and treated [5].

Statistical analysis: Data were analysed using Microsoft Excel software (from Microsoft Office 365). Both descriptive and inferential statistics were used to analyse the data. The frequency, standard deviation, percentage, means, growth rate, tables and charts were used to describe the data. The correlation analysis was carried out and the Pearson's moment correlation coefficient was calculated. Regression analysis was also carried out and the equation of the line of best fit was determined using the method of least square. A two-tailed student $\mathrm{T}$ test was used to compare the mean FHC in black population to that of Caucasian population.

\section{Results}

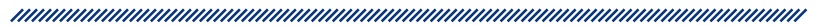

The data were collected from 324 pregnant women. Their ages range from 12 and 40 years (mean age 25.95 \pm 6.48$)$.

Table 1 shows the distribution of participants according to their tribes. Kanuris $(125=38.58 \%)$ were the majority, followed by Igbo ( $49=15.12 \%)$, Fulani $(24=7.4 \%)$, Hausa $(23=7.098 \%)$ and other minorities.

Figure 1 shows the age distribution of the participants. The majority of them were between 20 and 29 years old while very few were between 40 and 42 years old.

Figure 2 shows the distribution of the participants according to their presenting pregnancy ages. The majority $(151=46.6 \%)$ had a presenting pregnancy age between 30 and 40 weeks while the minority had a pregnancy age between 12 and 20 weeks.

Table 2 shows the mean, the standard deviation and the number of measurements made for each week ranging from 12 to 40 weeks.
Figure 3 shows a scatter diagram used to assess the correlation between the GA and the FHC. The coefficient of determination was $r^{2}=0.964$. Moreover, the equation of the line of best fit was computed and it is $Y=0.246 X+5.056$, where $Y$ is the average $G A$ and $X$ is the FHC. The calculated average growth rate per week was $3.81 \mathrm{~mm}$.

Table 3 compares the mean FHC in this study (black population) to that of Hill et al (Caucasians).

Table 4 shows the GA groups and their respective coefficient of determination. The coefficients of determination were $0.812,0.7864$ and 0.7247 for $12-20$ weeks, 21 30 weeks and 31-40 weeks respectively.

Figure 4, Figure 5 and Figure 6 show the correlation between the FHC and the BPD, the FHC and the $\mathrm{HC}$, and FHC and the FL respectively. They all show linear, highly positive and statistically significant correlations $\left(R^{2}=0.9595, p<0.001 ; \quad R^{2}=0.9465, p<0.001 ; \quad R^{2}=0.9628\right.$, $\mathrm{p}<0.001$ respectively).

A two-tailed student $T$ test showed there was a statistically significant difference between the mean of the measured FHC in the black population and those of Caucasian population $(\mathrm{p} \leq 0.036<0.05)$.

\section{Discussion}

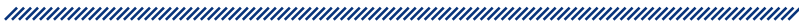

In this study we try to establish the possibility of using $\mathrm{FHC}$ in assessing the gestational age of the fetus using an ultrasound scan. For decades, ultrasound scanning of pregnant mothers has been evolving in resolution and routes of usage in obstetrics and gynaecology with better precision and accuracy in modern medicine. It is mostly used in assessing GA using a non-cardiac parameter (mean sac diameter, crown rump length, biparietal diameter and femur length), heart rate, fetal and placenta anomalies and fetal heart anomalies [24].

The majority of our participants are less than 30 years of age, mostly between 20-29 years of age (50.61\%), presenting mostly after 30 weeks gestational age (fig:12). At this period of time, the fetus is well developed and has already grown to some extent, reducing the probability of detecting fetal anomalies, as optimal fetal information is obtained when the scan is carried out 


\begin{tabular}{|c|c|}
\hline \multicolumn{2}{|c|}{$\begin{array}{l}\text { Table } 1 . \text { Distribution } \\
\text { of participants } \\
\text { according to their } \\
\text { tribes }\end{array}$} \\
\hline Tribe & $\begin{array}{c}\text { Number of } \\
\text { subjects }\end{array}$ \\
\hline Kanuri & $125(38.58 \%)$ \\
\hline Igbo & 49 (15.12\%) \\
\hline Fulani & $24(7.40 \%)$ \\
\hline Kuteb & $2(0.61 \%)$ \\
\hline Idoma & $6(1.85 \%)$ \\
\hline Marghi & 19 (5.86\%) \\
\hline Calabar & $1(0.30 \%)$ \\
\hline Hausa & $23(7.1 \%)$ \\
\hline Bura & $4(1.23 \%)$ \\
\hline Yoruba & $14(4.32 \%)$ \\
\hline Chibok & $1(0.30 \%)$ \\
\hline Shuwa & $15(4.63 \%)$ \\
\hline Kanakura & $1(0.30 \%)$ \\
\hline Dowaldi & $1(0.30 \%)$ \\
\hline Tiv & $2(0.61 \%)$ \\
\hline Edo & $4(1.23 \%)$ \\
\hline Babur & $1(0.30 \%)$ \\
\hline Mandara & $2(0.61 \%)$ \\
\hline Michika & $1(0.30 \%)$ \\
\hline Baseyap & $1(0.30 \%)$ \\
\hline Bayelsa & $1(0.30 \%)$ \\
\hline Hidi & $1(0.30 \%)$ \\
\hline Delta & $1(0.30 \%)$ \\
\hline Bago & $1(0.30 \%)$ \\
\hline Cross-river & $1(0.30 \%)$ \\
\hline Igala & $1(0.30 \%)$ \\
\hline Okoja & $1(0.30 \%)$ \\
\hline No tribe info. & $20(6.17 \%)$ \\
\hline
\end{tabular}

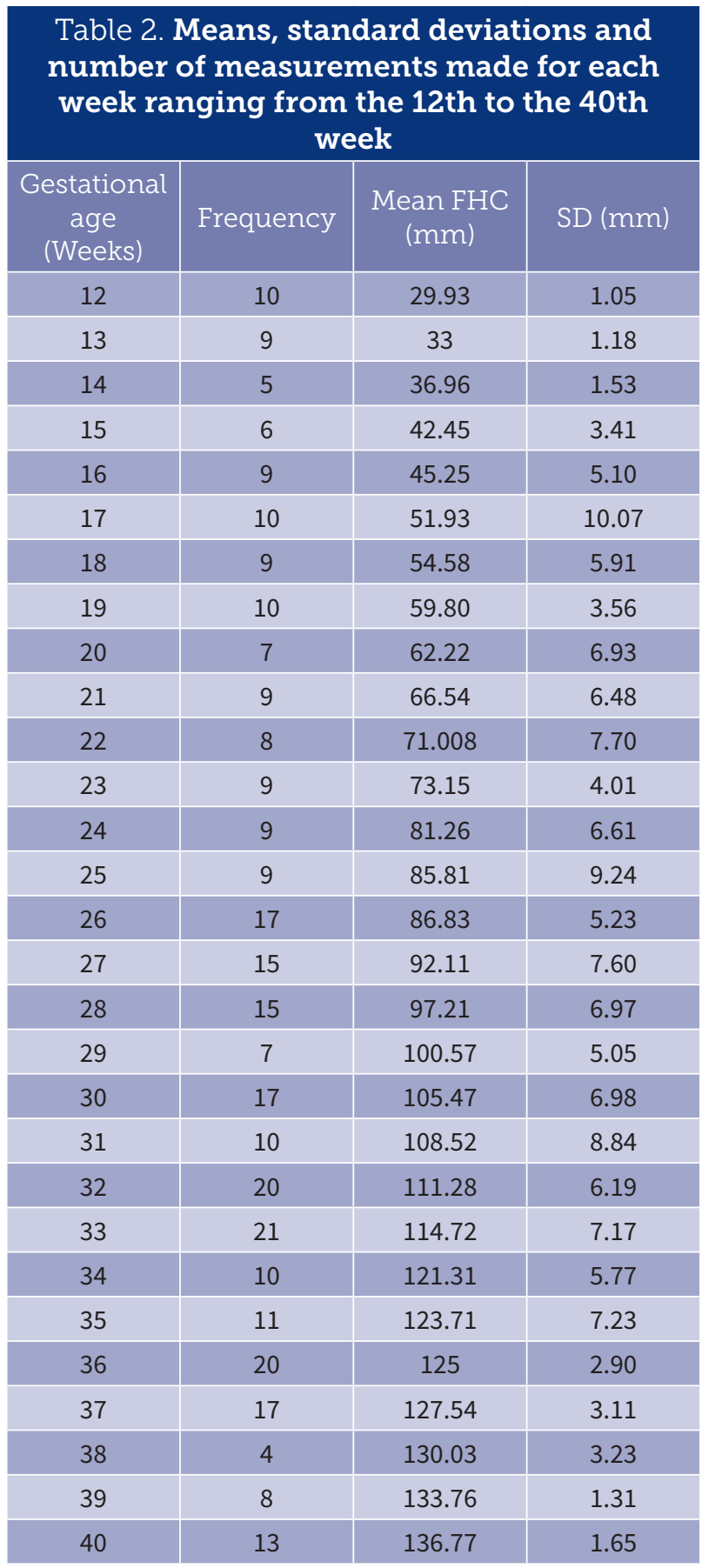

Table 3. Comparison between the mean FHC in this study of the black population and Caucasian population

\begin{tabular}{|c|c|c|}
\hline GA & Caucasians & Blacks \\
\hline 12 & & 29.93 \\
\hline 13 & & 33 \\
\hline 14 & & 36.96 \\
\hline 15 & 39 & 42.45 \\
\hline 16 & 48 & 45.25 \\
\hline 16 & 49 & 51.93 \\
\hline 18 & 58 & 54.58 \\
\hline 19 & 60 & 59.8 \\
\hline 20 & 65 & 62.22 \\
\hline 21 & 73 & 66.54 \\
\hline 22 & 79 & 71.008 \\
\hline 23 & 80 & 73.15 \\
\hline 24 & 80 & 81.26 \\
\hline 25 & 96 & 85.81 \\
\hline 26 & 106 & 86.83 \\
\hline 27 & 109 & 92.11 \\
\hline 28 & 112 & 97.21 \\
\hline 29 & 107 & 100.57 \\
\hline 30 & 118 & 105.47 \\
\hline 31 & 119 & 108.52 \\
\hline 32 & 126 & 111.28 \\
\hline 33 & 127 & 114.72 \\
\hline 34 & 135 & 121.31 \\
\hline 35 & 138 & 123.71 \\
\hline 36 & 145 & 125 \\
\hline 37 & 150 & 127.54 \\
\hline 38 & 150 & 130.03 \\
\hline 39 & 145 & 133.76 \\
\hline 40 & 154 & 136.77 \\
\hline 41 & 161 & \\
\hline 42 & 164 & \\
\hline
\end{tabular}




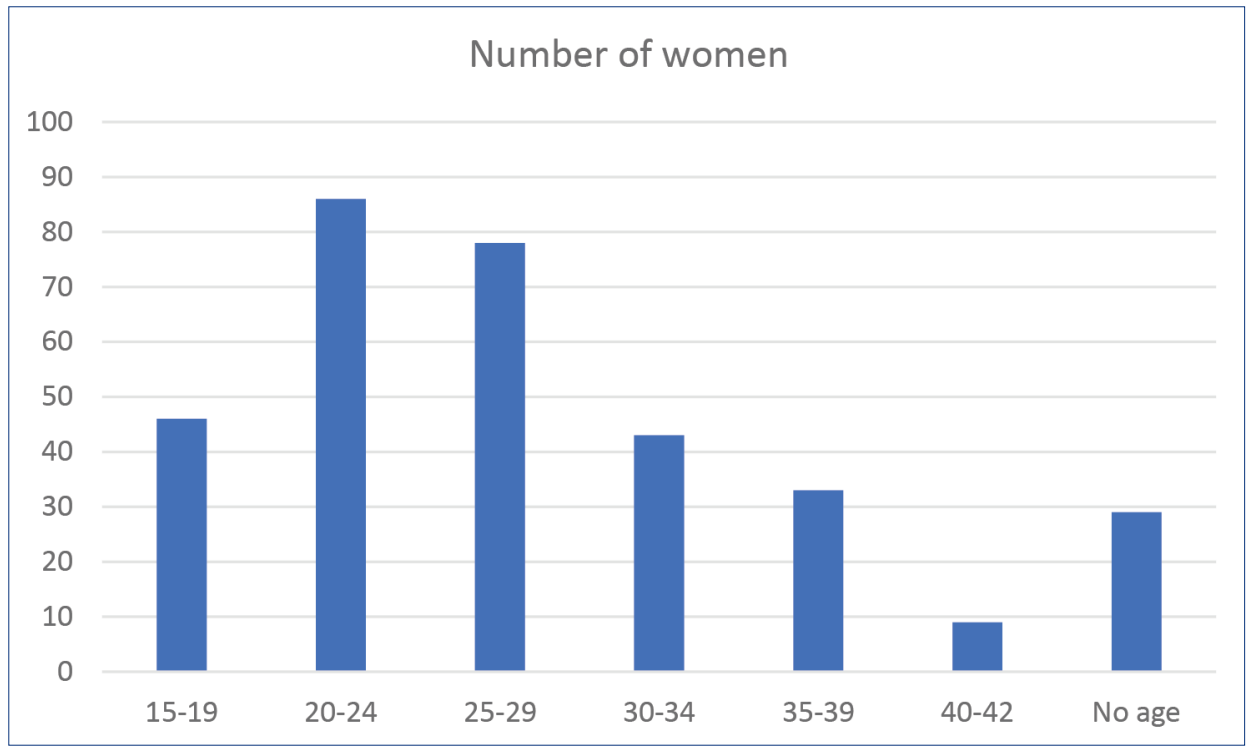

Figure 1. Age distribution of the participants

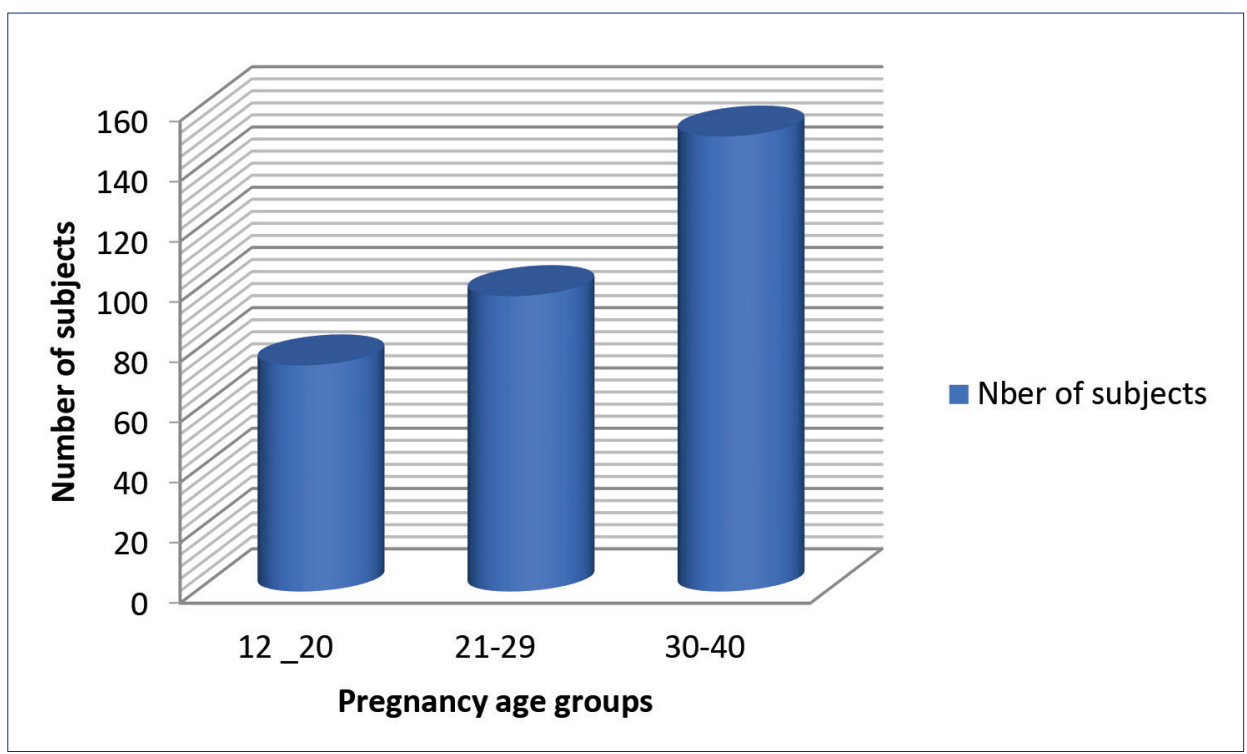

Figure 2. Distribution of participants according to their presenting pregnancy ages

\begin{tabular}{|c|c|}
\hline \multicolumn{2}{|c|}{ Table 4. Gestational age groups and their } \\
respective coefficient of determination.
\end{tabular}




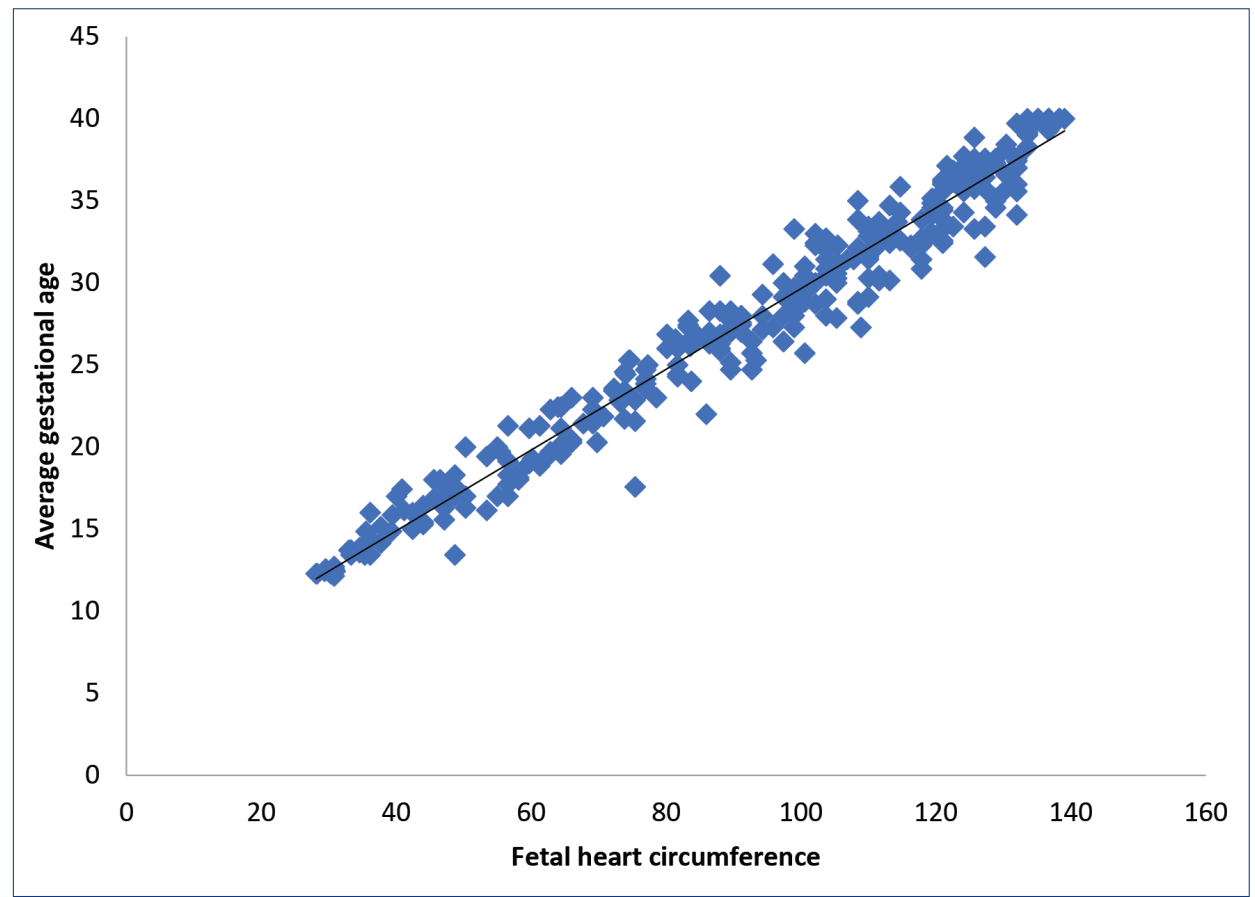

Figure 3. Distribution of observed FHC values at various points in gestation $\left(r^{2}=0.964, p \leq 0.001\right)$

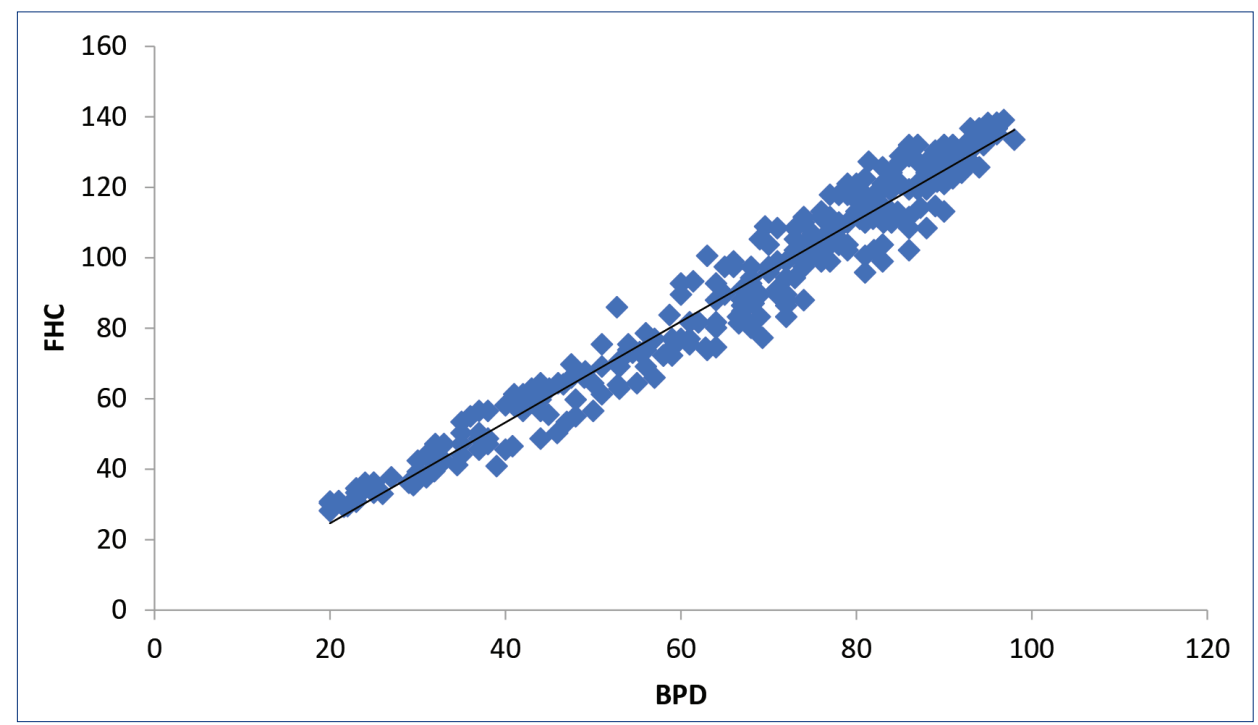

Figure 4. Scatter diagram of the FHC against the BPD $\left(r^{2}=0.9595, p \leq 0.001\right)$

between the $14^{\text {th }}$ and the $18^{\text {th }}$ week of gestation.[25]. Furthermore, in a review of 11 studies, it was shown that the second trimester ultrasound has an overall greater sensitivity $(41.3 \%)$ compared to the third trimester ultrasound (15.6\%).[26]. Therefore, women in this study locality should be sensitized more on the importance of early and anatomy ultrasound scans. They should also be informed about other benefits of ultrasound scan, e.g. detection of fetal anomalies. Dalinga et al, in a study conducted at the same institution (UMTH), also reported that the highest attendants at the antenatal clinic were women between 20-29 years and very few patients are above the age of 40 . In that study, it was also concluded that most of the women above 40 did not find the necessity for prenatal ultrasound scan as many had previous uneventful pregnancies without having an ultrasound done.[27]. It could also be justified by the decrease in fertility in that age group. There 


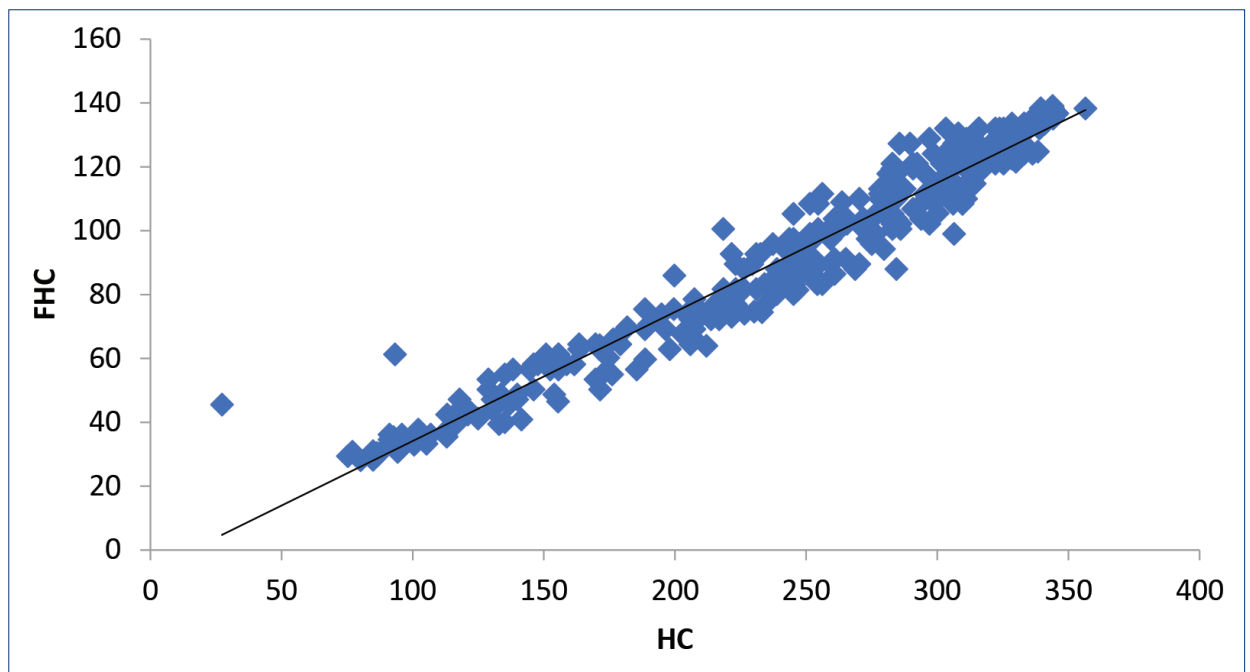

Figure 5. Scatter diagram of the heart circumference against the $H C\left(r^{2}=0.9465, p \leq 0.001\right)$

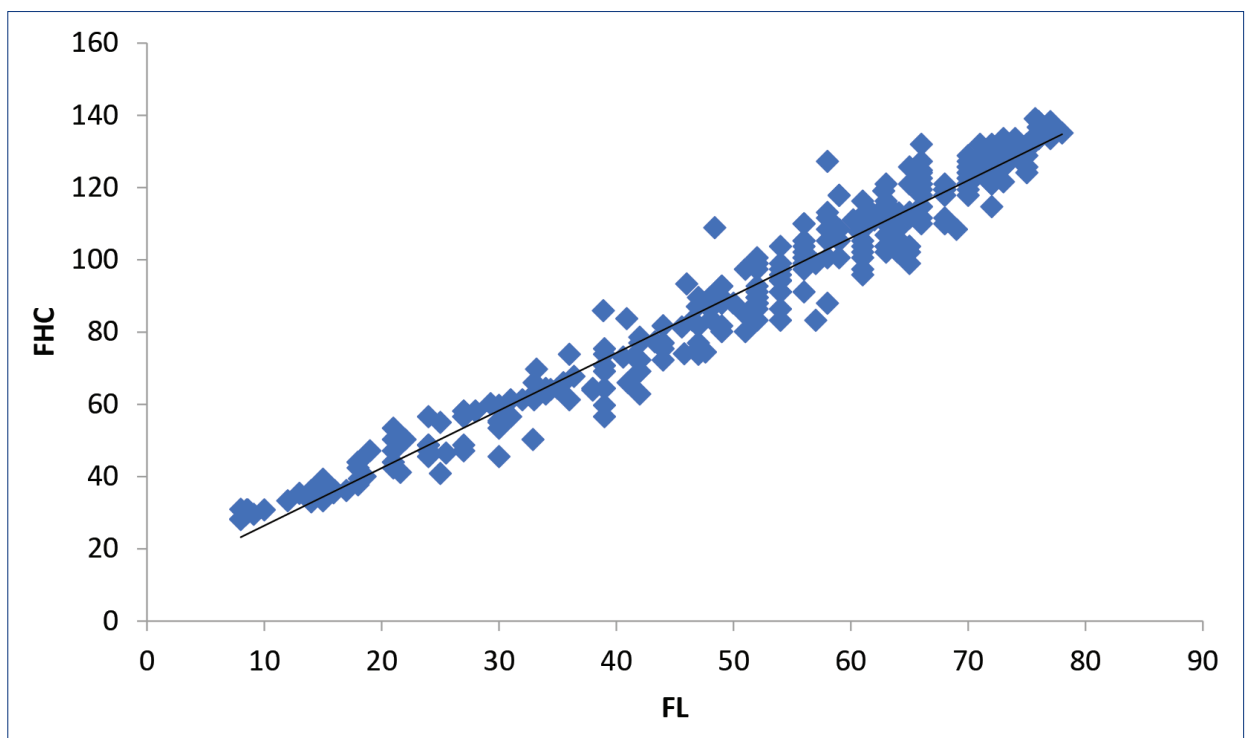

Figure 6. Scatter diagram of the heart circumference against the FL $\left(r^{2}=0.9628, p \leq 0.001\right)$

is need to create further awareness on the benefits of ultrasound scans.

In this study, the FHC appears to increase at a rate of $3.81 \mathrm{~mm}$ per week. This study shows a strong positive linear correlation $\left(r^{2}=0.96, P<0.001\right)$. These finding are similar with those obtained by Hill et al [15] and Jordaan [16]. In their studies, there was a strong correlation ( $r^{2}=0.94$ and $r^{2}=0.86$ respectively) between the FHC and the GA in normally growing fetuses. However, Jordaan [16] did not tabulate his data in a way that would permit GA assessment as the purpose of his research was to use FHC as an index for anomalous cardiac development.
In this study, there is a statistically significant difference between our values (blacks) and those of Hill et al (Caucasians) ( $p \leq 0.036<0.05)$. This is possibly due to racial differences. This could also be due to the difference in the study design and methods of data collection (FHC measurement methods), as Hill et al used the free hand tracing technique rather than two diameters at right angle to each other as we did.

This study further corroborates other studies that show a linear and statistically significant correlation between the FHC and other parameters (BPD, HC and FL) (shown in Figure 4,5 and 6). In Jordan et al. [18] and Gembruch et al. [28] studies however showed a strong linear cor- 
relation with between the $\mathrm{FHC}$ and the BPD, abdominal circumference (AC), GA and estimated fetal weight.

The present study also shows that $\mathrm{FHC}$ is more accurate in determining the GA when the ultrasound is done between 12 and 20 weeks of pregnancy age; and that accuracy reduces as the pregnancy progresses. This aligns with Verburg et al [29] who found that the earlier the ultrasound assessment the more accurate the prediction of the date of delivery.

Major limitations of this study are the small sample size and the uneven representation of the different ethnic groups which may make the result not generally applicable to the whole country, and to the black population. Likewise, modern scans now using high resolution transducers and 3D and 4D scans are way better than 2D scans in appreciation of fetal cardiac geometry for optimal analysis because of the changes as the pregnancy advances [30]. Other possible limitations to the use of FHC to determine the GA will probably be the changes in fetal heart morphology as the pregnancy advances. Data obtained in this study does not categorically demonstrate superior acceptability of FHC over conventional parameters like BPD, FL, CRP etc. in assessing GA, but shows a potential use in conditions where those parameters cannot be used or properly assessed.

Ethics approval and consent to participate: Approval was obtained for the research committee of the UMTH. The participants' consent was requested with regard to using their fetuses' parameters for research purpose. Measurements were taken only on those who accepted.

Conflict of Interest: Authors declare they have no competing interest.

Acknowledgements: The authors wish to express their gratitude to staff of the Radiology department, University of Maiduguri Teaching Hospital.

Funding Statement: This research received no specific grant from any funding agency in the public, commercial, or not-for-profit sectors.

\section{References}

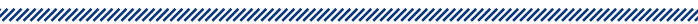

1. Carol B Benson, Peter M Doubilet. Sonographic prediction of gestational age: Accuracy of second- and third- trimester fetal measurements.AJR.1991; 157:1275-77.

2. Warda AH, Deter RL, Rossavik IK. Fetal femur length: a critical reevaluation of the relationship to menstrual age. Obstet Gynecol. 1985; 66:69

3. Mongelli M, Wilcox M, Gardosi J. Estimating the date of confinement: Ultrasonographic biometry versus certain menstrual dates. AmJ Obstet Gynecol. 1996; 174:278

4. Robinson H.P. A critical evolution of sonar crown rump length measurements. BJOG. 1975; 82:702-710

5. Johnsen Synnove Lian, Rasmussen Svein, Sollen Rita, Kiserud Torvid. Fetal age assessment based on femur length at 10-25 weeks of gestation and reference ranges for femur length to head circumference ratios. Acta Obstetrica et Gynecologica Scandinavica. 2005; 84(8):725-33

6. Kurmanvicius J. Ultrasonographic fetal weight estimation: Accuracy of formulas and accuracy of examiners by birth weight from 500 to 5000 grams. J.Perinat.Med. 2004; 32:155-161

7. Mercer BM. Fetal foot length as a predictor of fetal age. AmJ Gynecol. 1987; 156(2):350-355

8. R Napolitano, J Dhami, EO Ohuma, C Loannou et al. Pregnancy dating by fetal Crown Rump Length: A systematic review of chart. British journal of obstetrics and gynaecology. 2014; Vol 121, issue 5, pp 556 - 565

9. Chevernack F.A, Brightman R.C, Thomton J, Berkowitz Z, G.S Davids. Crown rump length and serum human chorionic gonadotropin as predictor of the gestational age. Obstet Gynecol. 1986; 12:343-346

10. A Beigi, F Zarrinkoub. Ultrasound assessment of fetal biparietal diameter and femur length during normal pregnancy in Iranian women. International Journal of Obstetrics and Gynaecology. 2000; 69:237-242

11. Hadlock F.P, Deter R.L, Harrist R.B. Fetal biparietal diameter, a critical reevaluation to menstrual age by means of real tine ultrasound. J. Ultrasound in Medicine. 1982 1:97

12. F.P Hadlock, R.B Harrist, R.L Deter, S.S Park. A prospective evaluation of the femur length as a predictor of the gestational age. Journal of ultrasound in medicine 1983;2(3):111-112

13. Konje JC, Abrams KR, Bell SC, Taylo DJ. Determination of gestational age after 24 weeks of gestation from fetal kidney length measurements. Ultrasound Obstet Gynecol. 2002; 19(6):592-7

14. F.P Hadlock, R.B Harrist, R.L Deter, S.S Park. AJR Am J Roentgenol. 1982; Apr; 138(4): 649-53.

15. Hill L.M, Guzick D, Peterson C, Dinofrio D, Malone J, Nedzeksy P. Fetal heart circumference as a predictor of menstrual in fetuses affected by disturbances of growth 
American journal of Obstetrics and Gynecology. Vol. 169, Issue 2, Part 1, August 1993, Pages 347-351

16. Jordaan HVF. Cardiac size during prenatal development. Obstet Gynecol 1987; 69: 854- 88.

17. Hyett $J$ et al Fetal heart rate in trisomy 21 and other chromosomal abnormalities at 10-14 weeks GA .Uscan Obstet Gynaecol 1996;7:239-244

18. World Medical Association Declaration of Helsinki Ethical Principles for Medical Research Involving Human Subjects. JAMA 2013; 310(20):2191-2194. Downloaded from: http://jama.jamanetwork.com/ by an American Medical Association User on February 22, 2018. doi:10.1001/ jama.2013.281053

19. Jeanty P, Romero R, Francis Cantraine, et al. Fetal cardiac dimensions, a potential tool for the diagnosis of congenital heart defects. J. Ultrasound Med. 1984; 3: 359-64

20. D.G.Altman, L.S Chitty. New chart of ultrasound dating in pregnancy. Ultrasound Obstet.Gynecol. 1997; 10:174-191

21. Hobbins JC. Fetal biometry. Obstetric Ultrasound: Artistry in Practice. USA: Blackwell Publishing; 2008 pp 39 - 43 ISBN: 978-1-4051-5815-2

22. Marlon I, Ahmed B and Miskovic B. Chapter 5: Basic biometry. Cited in; D’Addario V. Donald School Basic Textbook of Ultrasound in Obstetrics \& Gynecology. 2nd ed. New Delhi: JP Medical Ltd; 2014. pp. 53-58.

23. Campbell S, Warsolf SL, Little D, Cooper DJ. Routine ultrasound screening for the prediction of gestational age. Obstet gynecol.1985; 65:613-620

24. Wisser J et al. Embryonic heart rate in dated human embryos. Early Hum Dev 1994;37:107-115.
25. D.A. G Imoedemhe, E.Milford, R Chan and Djahanbackch. Evaluation of routine early pregnancy ultrasonography. Acta Obstetrica and Gynecologice Scandinavica. 1985; 64(5): 427-431

26. Bricker L, Garcia J, Henderson J, Mugford M, Neilson $\mathrm{J}$, Roberts $\mathrm{T}$, et al. Ultrasound screening in pregnancy: a systematic review of the clinical effectiveness, costeffectiveness and women's views. Health Technology Assessment. 2000;4:1-193.

27. Dalinga Husaini Shallangwa. Awareness and utilization ultrasound scan among antenatal patients. A case study of University of Maiduguri Teaching Hospital. 2008; p3 and p32 (unpublished). Thesis submitted to the radiography department of the university of Maiduguri as part of the fulfilment of the bachelor degree in Radiography.

28. Gembruch U, Shi C,Smrcek J. Biometry of fetal heart between 10 and 17 weeks GA.Fetal diagnosis Ther 2000;15:20-31

29. Verburg B.O, Steegers E.A, De Ridder M, Snijders R.J, Hofman.A, Moll.H.A, Jaddoe V.M, Witteman J.C. New chart of ultrasound dating of pregnancy and assessment of the fetal growth. Longitudinal-based Cohort study. $\mathrm{Ul}$ trasound Obstet Gynecol. 2008; 31(4): 388-396.

30. Espinoza J, Gotsch F, Kusanovic JP, et al. Changes in fetal cardiac geometry with gestation: implications for 3and 4-dimensional fetal echocardiography. J Ultrasound Med. 2007;26(4):437-444. doi:10.7863/jum.2007.26.4.437 


\section{ULTRAZVUČNA PROCJENA CIRKUMFERENCIJE FETALNOG SRCA KAO PREDIKTOR GESTACIJSKE DOBI}

\author{
1 Carnot N Ntafam \\ 2 Nwobi Ivor \\ 1 David Otohinoyi \\ 1 Okikiade Adedeji \\ 3 Joseph Dimas \\ 1 All Saint University School of Medicine, St Vincent Campus \\ 2 Department of Radiography, University of Maiduguri \\ 3 Department of Radiology, Federal Medical Centre, Katsina
}

\section{Sažetak}

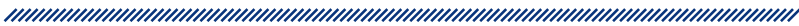

Uvod: Ultrazvuk je neinvazivni način snimanja, siguran za majku i fetus, koji upotrebljava visokofrekventne zvučne valove za stvaranje slika tjelesnih tkiva i organa. Uvelike se primjenjuje za fetalnu procjenu i datiranje.

Svrha: Utvrditi normativne vrijednosti cirkumferencije fetalnog srca (FHC) kao prediktora gestacijske dobi (GA) u populaciji crnaca i usporediti je s onom kod bijelaca.

Materijali i metode: Prospektivna presječna studija provedena je u Sveučilišnoj bolnici Maiduguri u Nigerija. 324 žene s jednoplodnom trudnoćom između 12 i 40 tjedna trudnoće, koje su začele prirodnim putem, pregledane su s pomoću 2D ultrazvučnog aparata sa zakrivljenom sondom od 3,5 MHz. Snimljena su dva promjera fetalnog srca pod desnim kutom na razini prikaza četiriju srčanih komora tijekom dijastole.

Rezultati: Postoji snažna pozitivna linearna korelacija između cirkumferencije fetalnog srca (engl. fetal he- art circumference - FHC) i gestacijske dobi (engl. gestational age $-\mathrm{GA})(\mathrm{r} 2=0,964, \mathrm{p}<0,001)$. Jednadžba za predviđanje gestacijske dobi jest $Y=0,246 X+5,06$ (gdje je $y=G A, X=F H C$ ). Tjedna stopa rasta FHC-a iznosi $3,81 \mathrm{~mm}$. FHC je točniji između 12 i 20 tjedna gestacije i njegova se točnost smanjuje kako trudnoća odmiče. Postoji jaka korelacija između $\mathrm{FHC}$-a i biparijetalnog promjera (engl. biparietal diameter - BPD) $(r 2=0,959)$, $\mathrm{HC}(\mathrm{r} 2=0,946)$ i duljine bedrene kosti (engl. femoral len$g$ th $-\mathrm{FL})(\mathrm{r} 2=0,962)$.

Zaključak: Studija je rezultirala izradom nomograma FHC-a kao prediktora gestacijske dobi u nigerijskoj populaciji i pokazala je da je FHC dobar prediktor gestacijske dobi, posebno u ranom drugom tromjesečju. Također, postojala je statistički značajna razlika između FHC-a u našoj istraživanoj populaciji (crnci) i populaciji bijelaca.

Ključne riječi: cirkumferencija fetalnog srca (FHC), gestacijska dob (GA), ultrazvučno skeniranje, nomogram 